\title{
Integrated studies for characterization of lineaments used to locate groundwater potential zones in a hard rock region of Karnataka, India
}

\author{
Subash Chandra $\cdot$ V. A. Rao • N. S. Krishnamurthy • \\ S. Dutta $\cdot$ Shakeel Ahmed
}

\section{Publisher's Note: \\ Hydrogeology Journal (2006), pp 767-776 \\ DOI 10.1007/s10040-005-0480-3}

The figures in this article were inadvertently printed in black and white instead of in colour. We apologize very much for this error and provide you here with the corrected printed version.

\begin{abstract}
An integrated study was carried out to investigate the subsurface geological conditions in a hard rock environment, with the aim of identifying zones with groundwater resource potential. The study, in Bairasagara watershed, Karnataka, India, considered geomorphology, water level, resistivity imaging, self potential, total magnetic field and susceptibility. The signatures due to lineaments have been clearly identified and their role in groundwater movement has been documented. Synthetic simulation methods were used to model the electrical response of the lineament using finite differential modeling scheme. The inverted image of the field data is compared with the synthetic image and iteration were performed on the initial model until a best match was obtained resulting on the generation of the calibrated resistivity image of the subsurface. Resistivity imaging revealed that the dykes are weathered/fractured to a depth of 6-8 m and are compact at deeper levels, and that they behave as barriers to groundwater movement, yet facilitate a good groundwater potential zone on the upgra-
\end{abstract}

Received: 8 July 2005 / Accepted: 22 August 2005

Published online: 29 August 2006

(C) Springer-Verlag 2006

The online version of the original article can be found at http://dx.doi.org/10.1007/s10040-005-0480-3

S. Chandra $(\bowtie) \cdot$ V. A. Rao $\cdot$ N. S. Krishnamurthy $\cdot$ S. Dutta S. Ahmed

Indo-French Center for Groundwater Research (IFCGR), National Geophysical Research Institute,

Uppal Road, Hyderabad 500007, Andhra Pradesh, India e-mail: schandra_k@yahoo.com/chandra_sngri@rediffmail.com

Tel.: +91-040-23434681

Fax: +91-040-23434651 dient side. The results of magnetic surveys were utilized in differentiating granites and dolerite dykes with an insignificant resistivity contrast. Geomorphological expression alone cannot reveal the groundwater potential associated with a lineament. However, characterizing the nature of the feature at depth with integrated geophysical methods provides essential information for assessing that potential.

Résumé Une étude a été réalisée sur la géologique de sub-surface en milieu rocheux fracturé, avec pour objectif l'identification des zones possédant des potentiels de ressource en eau souterraine. Cette étude, sur le bassin versant de Bairasagara, Karnataka, prend en compte la géomorphologie, le niveau de l'eau, les images de résistivité, le self potentiel, le champ magnétique total et la susceptibilité. Les signaux dus à la présence de linéaments, ont été clairement identifiés ainsi que leur influence sur le mouvement des eaux souterraines. Les méthodes de simulation synthétique ont été utilisées pour modéliser la réponse électrique des linéaments, en utilisant une modélisation par différences finies. L'image inversée des données de terrain est comparée avec l'image synthétique; des itérations sur le modèle initial ont été mises en œuvre jusqu'à un rapprochement optimal, résultant en la génération d'une image calibrée de la résistivité de la sub-surface. Les images de résistivités révèlent que les dykes sont altérés et fracturés sur une profondeur de 6 à 8 mètres et sont compactés à des profondeurs plus importantes. Les dykes se conduisent dés lors comme des barrières au mouvement des eaux souterraines. Cependant ils favorisent un bon potentiel, du point de vue de la remontée des gradients. Les résultats des levés magnétiques ont été utilisés pour différencier les dykes de granite et les dykes de dolérite avec des contrastes de résistivité trop faibles. L'étude géomorphologique seule n'aurait pu suffire à comprendre le potentiel des eaux souterraines associé aux linéaments. Par ailleurs, la caractérisation des formes en profondeur avec des méthodes de géophysique intégrée, apporte des informations essentielles pour réaliser un bilan des potentiels.

Resumen Un estudio integrado se llevó a cabo para investigar las condiciones geológicas del subsuelo en un ambiente de rocas duras, con el objetivo de identificar las zonas con potencial de recurso de agua subterránea. El estudio, en la cuenca de Bairasagara, Karnataka, incluyó geomorfología, nivel de agua, proyección de imágenes de 
resistividad, auto potencial, campo magnético total y susceptibilidad magnética. Los rasgos característicos debidos a los lineamientos se han identificado claramente y su papel en el movimiento del agua subterránea se ha documentado. Se usaron los métodos de simulación sintéticos para modelar la respuesta eléctrica del lineamiento, mediante el uso de un esquema de modelación de diferencias finitas. La imagen invertida de los datos del campo se comparó con la imagen sintética y se realizó iteración en el modelo inicial hasta que se logró la mejor coincidencia, que resultó en la generación de la imagen de la resistividad calibrada del subsuelo. Las proyecciones de imágenes de resistividad, revelaron que los diques están meteorizados y fracturados hasta una profundidad de 6-8 $\mathrm{m}$ y son compactos a niveles más profundos, y que ellos se comportan como barreras al movimiento del agua subterránea, aunque contribuyen a formar una zona con buen potencial en el sector de aguas arriba. Se utilizaron los resultados de los estudios magnéticos para diferenciar granitos y diques de dolerita que poseen un contraste de resistividad insignificante. La expresión geomorfológica por si sola no puede revelar el potencial del agua subterránea asociada con un lineamento. Sin embargo, al caracterizar la naturaleza del rasgo en profundidad con los métodos geofísicos integrados, se obtiene la información esencial para evaluar ese potencial.

Keywords Integrated studies - Lineaments . Groundwater resources · Electrical resistivity imaging (ERI) $\cdot$ Hard rock

\section{Introduction}

Groundwater is the major source of water supply needed for industrial, agricultural and domestic purposes in many semi-arid regions of India. In some cases, over-exploitation has resulted in declining groundwater levels and has consequently confined groundwater flow to deeper weathered/fractured zones. Therefore, it became essential to study these zones to determine their potential for supporting groundwater resources in order to meet demand (hereafter termed 'groundwater potential zones'). Lineaments, large-scale linear features expressed in topography including valleys and underlying structural features controlled by faults or joints especially in hard rock areas, are good water potential zones. Areas upgradient of dykes or any other geological intrusions within the host rock are also good water potential zones, where the dyke/intrusion behaves as a barrier to groundwater flow. Lineament has generally been used as an indicative tool for locating groundwater potential zones (Lattman and Parizek 1964; Siddiqui and Parizek 1971; Yin and Brook 1992; Mabee et al. 1994; Gustafsson 1994; Mahmood 1996; Sander 1997; Sander et al. 1997; Edet et al. 1998; Magowe and Carr 1999; Mabee et al. 2002), but with the present scenario of over-exploitation of the aquifer, characterization of the lineament becomes essential to ensure the possibility of locating groundwater potential zones and managing over-exploited aquifers in hard rock terrain.

In an over-exploited area of hard rock terrain in Karnataka, India, where the groundwater level was drawn down (approximately $40 \mathrm{~m}$ ), the lineament marked in the geomorphological map alone was not sufficient to locate groundwater potential zones without considering other parameters like bed rock depth, over burden type, topographic position, and proximity to surface water bodies.

Geophysics can play a major role in defining these parameters. The traditional groundwater exploration in India, has been based on a single geophysical technique, where boreholes are sited on anomalies identified by electrical resistivity methods, often with little understanding of the geological structure of the target area. In many areas of complex hydrogeology, these techniques often fail for a variety of reasons, eg. ambiguities in identifying the geophysical anomalies, lack of adequate understanding of the occurrence of groundwater and other factors affecting permeability in these terrains. To address these problems an integrated study would contribute to greater success in the exploration process and reduce the ambiguity for groundwater exploration in hard rock areas.

The purpose of this study in Karnataka was to demonstrate the need for an integrated approach in a hard rock area, where groundwater over-exploitation (due to population increase and socio-economic development, mining activities and associated settlements, small-scale irrigation, rural agro-industries, and livestock etc) is causing groundwater depletion. Integrated geomorphological, geological, hydrological, electrical resistivity imaging, self potential and magnetic studies have been carried out to characterize the lineaments that are groundwater potential zones in the Bairasagara watershed.

The study area, shown in Fig. 1, covers $111 \mathrm{~km}^{2}$ and lies between Latitudes $13^{\circ} 32^{\prime} 20^{\prime \prime}$ and $13^{\circ} 41^{\prime} 24^{\prime \prime} \mathrm{N}$, and Longitudes $77^{\circ} 39^{\prime} 25^{\prime \prime}$ and $77^{\circ} 45^{\prime} 15^{\prime \prime} \mathrm{E}$. This is an over-exploited area and falls within a semi-arid region. The average rainfall for the last 13 years (1990-2003) was about $700 \mathrm{~mm} / \mathrm{y}$. The increasing stress on groundwater resources has resulted in the drying up of shallow boreholes and wells. Thus a need arises to explore the deeper water potential zones to fulfill the growing groundwater demand.

The rocks in the study area belong to the Dharwar Super Group of the Archean Era. They are mainly composed of granites and granitic gneisses, which are exposed in small hillocks. Shear zones have also been recorded at a few places near Bachchanahalli and Bairasagarakere, running along the Kushawati River (in S-N direction). The regional geological sequence has been classified into a lower hornblendic division consisting of hornblende-schist, calc-granulites, hematite-quartzite, magnetite etc., and an upper (younger) chloritic division made up of chlorite mica-schists, quartzites, marbles, ferruginous quartzite etc. (Mukerjee 1986). Geological studies have indicated that the area is traversed by a large number of dolerite dykes, shown in Fig. 2, which were confirmed by thin section analysis showing ophitic and sub-ophitic texture. 


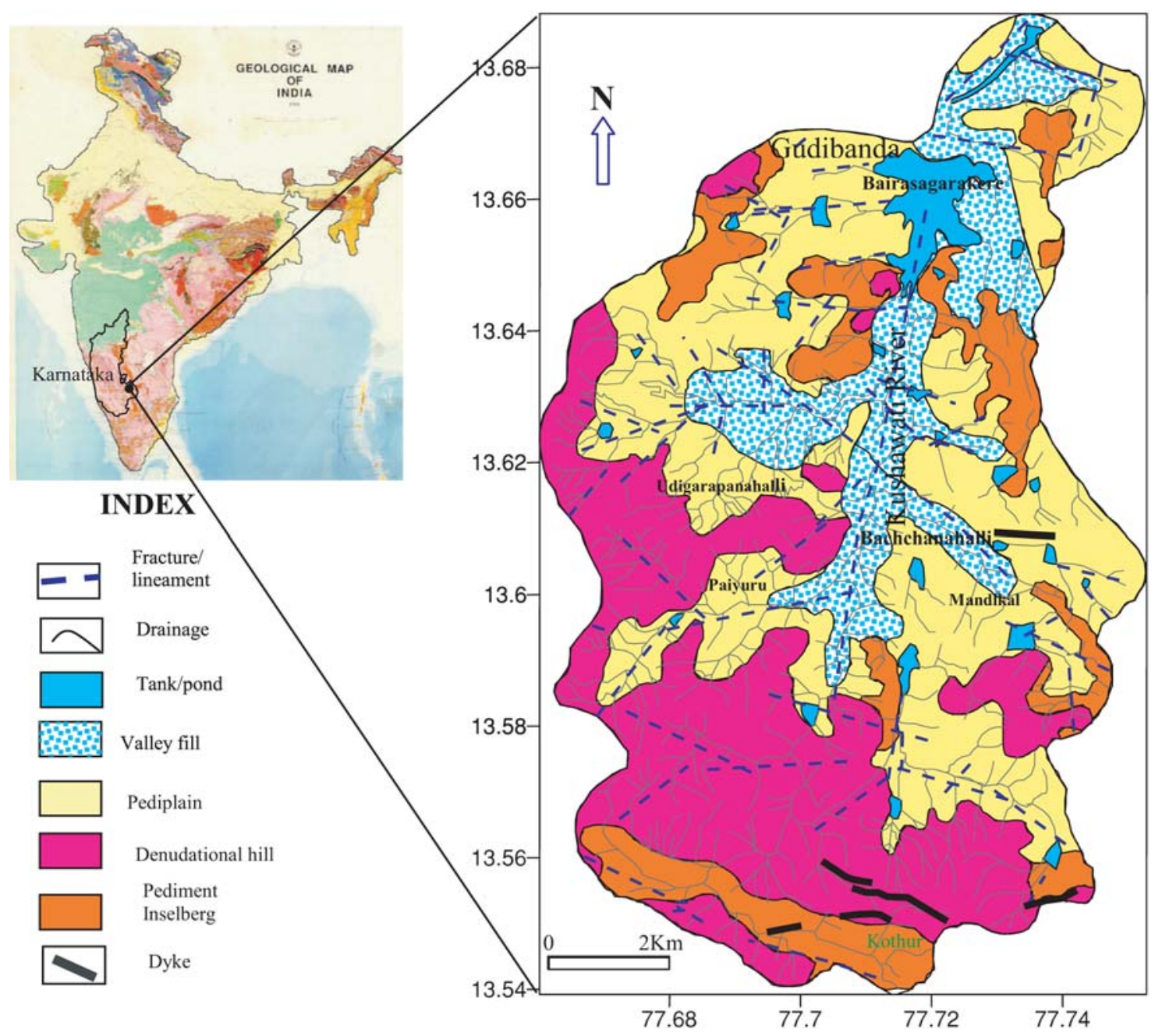

Fig. 1 Location and geomorphological map of Bairasagara Watershed, Kolar district, Karnataka

Figure 3 shows the area has an undulating topography and has undergone weathering to a depth of $20 \mathrm{~m}$. Weathering of granite rocks has formed red soils, red sandy soil and gravel. Weathering of the dolerite dyke results in the formation of black soils. Beneath the weathered portions the rocks are well jointed, favouring secondary porosity.

\section{Geomorphology and hydrogeology}

Study of the geomorphologic map of the area (Fig. 1) shows that the northern part of the basin is covered by pediplain, while the southern part is mostly covered by denudational hills. The main drainage, i.e. the Kushawati River, is underlain by valley fill. A number of lineaments appear on the geomorphological map in the form of fractures and dykes. A long fracture has been shown running along the river in a south-north direction, which finally meets the Bairasagarakere, the main water storage surface body (tank). A few groups of dykes also appear in the southern portion as well as one near Mandikal village running in the $\mathrm{E}-\mathrm{W}$ direction.
The main input to groundwater is precipitation (i.e. rainfall) and, to a minor extent, infiltration of water from the ponds and surface water applications. Groundwater occurs in the fractures, joints, fissures and weathered zones of the basement rock below the water table, under semi-confined conditions (Chand et al. 2004). Joints and fractures have also been recorded at depths below $10 \mathrm{~m}$. These weaker zones/planes might act as major conduits for groundwater flow. The pre-monsoon and post-monsoon groundwater levels were monitored regularly during 2001-2003 in 71 observation wells (see Fig. 2), which were recorded relative to the mean sea level using-differential Global Positioning System (DGPS). The water table in the study area varies from 10 to $40 \mathrm{~m}$ below ground level (bgl). The groundwater gradient causes flow towards the north (Fig. 3).

\section{Geophysical studies}

\section{Magnetic methods}

Since dykes have fairly high signatures in a low magnetic granite host medium (Atchuta Rao et al. 1981; Haricha- 
Fig. 2 Location map of observation wells, dykes and lineaments

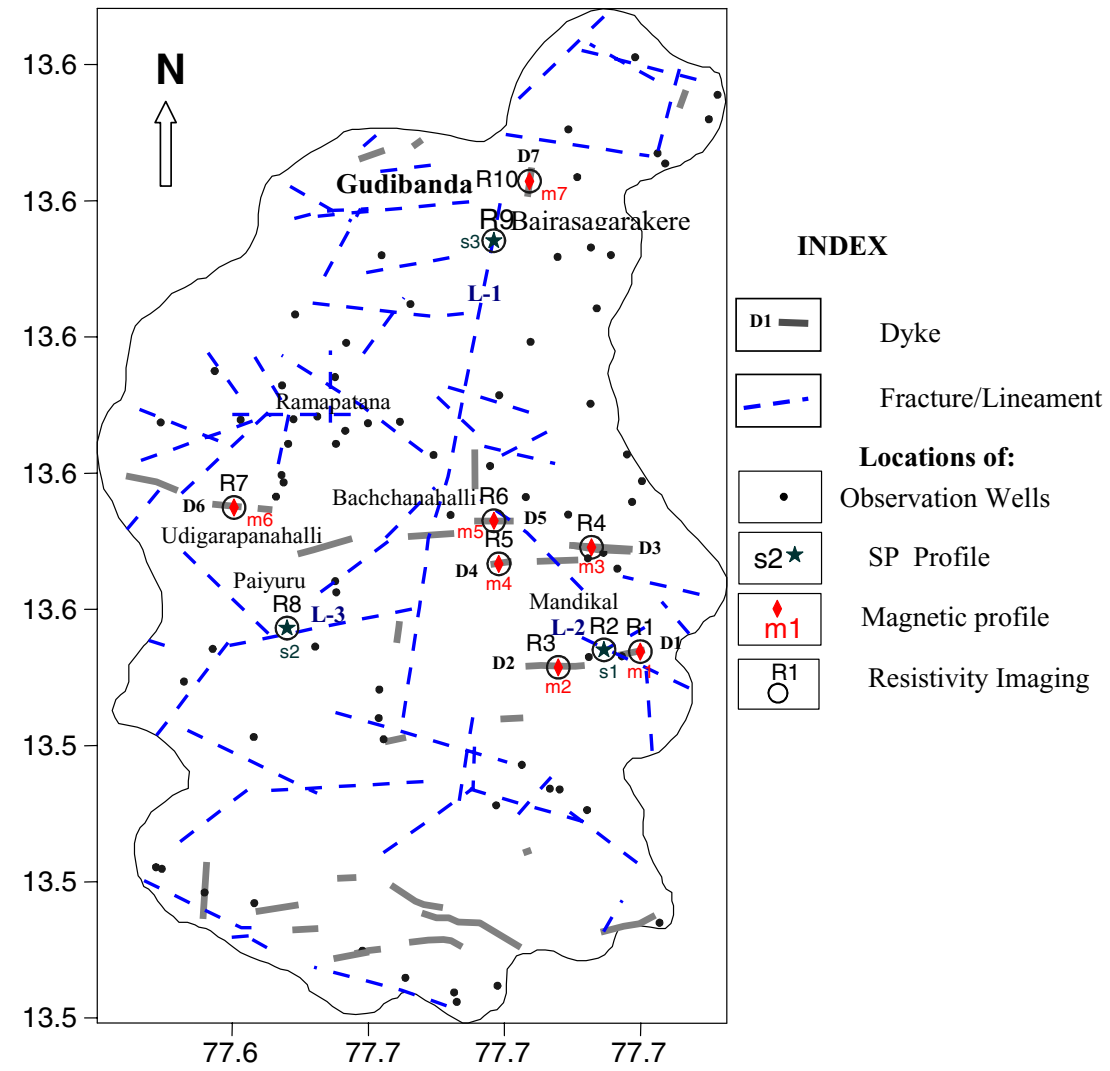

ran et al. 1984) magnetic profiling was carried out along 7 profiles ( $\mathrm{m} 1$ to $\mathrm{m} 7$, see Fig. 2) crossing several dykes (D1 to D5 in the central region, plus two others, see Fig. 2) using a proton precession magnetometer (PPM). The total magnetic field was measured as $3.95 \times 10^{-5}$ $4.2 \times 10^{-5}$ Tesla $(\mathrm{T})$. The magnetic susceptibility measured for dolerite dykes varies from $2.6 \times 10^{-2}$ to $5.1 \times 10^{-2} \mathrm{Am}$ pere/meter $(\mathrm{A} / \mathrm{m})$, and for granite gneiss, $3.0 \times 10^{-3}$ to $5.0 \times 10^{-2} \mathrm{~A} / \mathrm{m}$ respectively. The significant contrast of the total magnetic field and the magnetic susceptibility between granite and dolerite dyke has shown it's useful application in order to identify and characterize the lineament.

\section{Electrical resistivity imaging (ERI) method}

Improvement in resistivity methods using multi-electrode arrays has led to an important development in electrical imaging for subsurface surveys (Barker 1978; Griffiths and Turnbull 1985; Griffiths et al. 1990; Barker 1992; Griffiths and Barker 1993). Such surveys are usually carried out using a large number of electrodes connected through a multi-core cable. A laptop microcomputer together with an electrode-switching unit is used to automatically select the four relevant electrodes for each measurement. Apparent resistivity measurements are recorded sequentially sweeping any quadruple (current and potential electrodes) within the multi-electrode array. Resistivity variation was measured at shallow depth within pseudo-sections, yielding high recording density in a short period of time. It allows the detailed interpretation of 2D resistivity distribution in the ground (Loke and Barker 1996). Multielectrode resistivity imaging techniques were used in this study.

The lateral or near surface inhomogeneity effect which is commonly observed in conventional resistivity sounding curves (Koefoed 1979) is minimized by taking dense measurements with number of stack (3-10) at each sample point. Very few studies have been carried out in India using such a computer-controlled multi-electrode electrical resistivity meter (Krishnamurthy et al. 2003a; Krishnamurthy et al. 2003b). Similar studies were carried out by Barker et al. 2001, where the sequential observations were recorded manually instead of by a computer-controlled resistivity meter. The apparent resistivity data obtained from the field were inverted for a two dimensional (2D) resistivity image using RES2DINV (Griffiths and Barker 1993). Electrical Resistivity Imaging was carried out along 10 profiles (R1 to R10 in Fig. 2) using WennerSchlumberger and pole-pole configuration with a 48 electrode set, 5 and $10 \mathrm{~m}$ inter electrode spacing, across the lineaments/dykes to confirm their presence as well as to study their nature. The synthetic ERI responses were computed over different conductive and non conductive vertical bodies inter-bedded in a layered formation using RES2DMOD (Loke 2001) that yields apparent resistivity data, and RES2DINV that inverts the apparent resistivity data in order to produce the electrical resistivity image. The inverted ER image of the field data was compared with the synthetic ER image and iterations were performed on 
Fig. 3 (a) Topographic view Groundwater level (amsl), in March 2002 above mean sea level (amsl), (b)

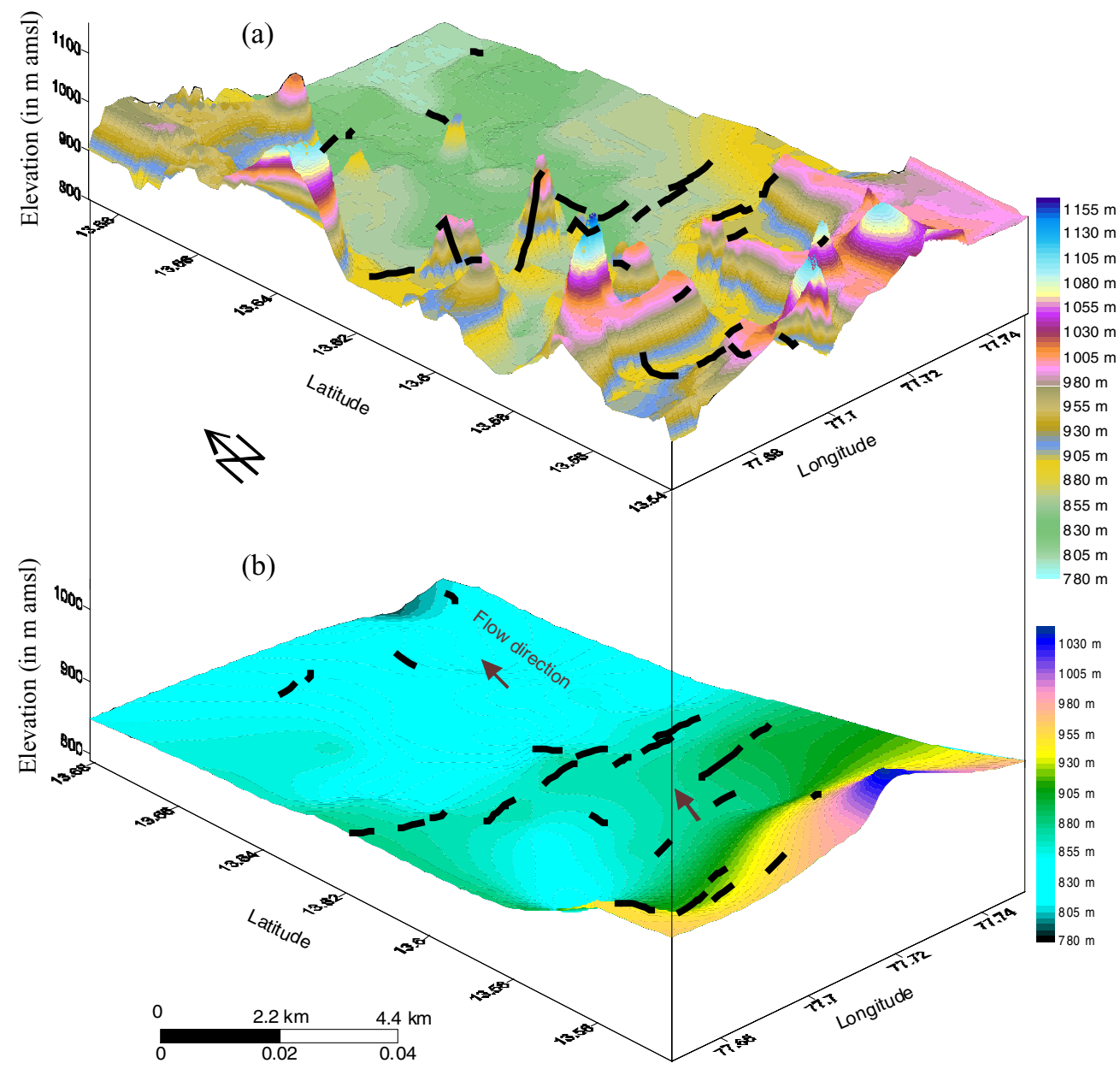

the initial model until a best match was obtained resulting in the generation of the calibrated resistivity image.

\section{Self potential method}

Self potential (SP) profiling was also employed to indicate the presence of lineaments in hard rock areas because the groundwater movement is generally confined to the lineament e.g. fractures, faults and shear zones etc. The previous studies have shown useful applications of self potential for groundwater studies (Wanfang et al. 1999; Krishnamurthy et al. 2001; Baker and Cull 2004; Fagerlund and Heinson 2003). SP is caused by groundwater flow, salt diffusion in porous media and the relative petrophysical rock properties such as coefficients of streaming current and diffusion current. It is well known that electrical potential (streaming potential) is generated when ground water flows in a permeable subsurface layer/lineament due to a hydraulic pressure gradient (Ahmed 1964; Parkhomenko 1971). The presence of a hydraulic pressure gradient in the subsurface, however, is not a sufficient reason to assume the existence of electric potential on the surface. As described by Fitterman (1979), it is necessary to have a pressure gradient parallel to a boundary that separates the regions of different streaming potential coefficients. Therefore self potential (SP) was also measured across three lineaments/dykes (s1 to s3 in Fig. 2).

\section{Results and discussion}

A combined interpretation of the geological, hydrogeological, and geophysical data was carried out to identify lineaments with deep groundwater potential zones at Bairasagara watershed. The studies were more concentrated in the central part, where a number of dykes are exposed. These dykes mostly run in an E-W direction whereas the general groundwater movement is towards the north, as shown in Fig. 3, i.e. perpendicular to the strike of the dykes. Studies over dyke (D5) at Bachchanahalli, lineament (L-2) at Mandikal tank and lineament (L-1) at Bairasagarakere are described below:

\section{Dyke (D-5) at Bachchanahalli}

A profile across the dyke D-5 has shown a strong magnetic anomaly (Fig. 4a). A magnetic susceptibility contrast (around $37 \times 10^{-3} \mathrm{~A} / \mathrm{m}$ ) between the intrusive and the host granite formation has confirmed the presence of a dolerite dyke. The 2-D resistivity section (R-6) at Bachchanahalli has clearly shown the presence of the dyke (Fig. 4b). The resistivity image reveals that the dyke is weathered/fractured to a depth of $6 \mathrm{~m}$. In the section at shallower depth, the re- 
(a)

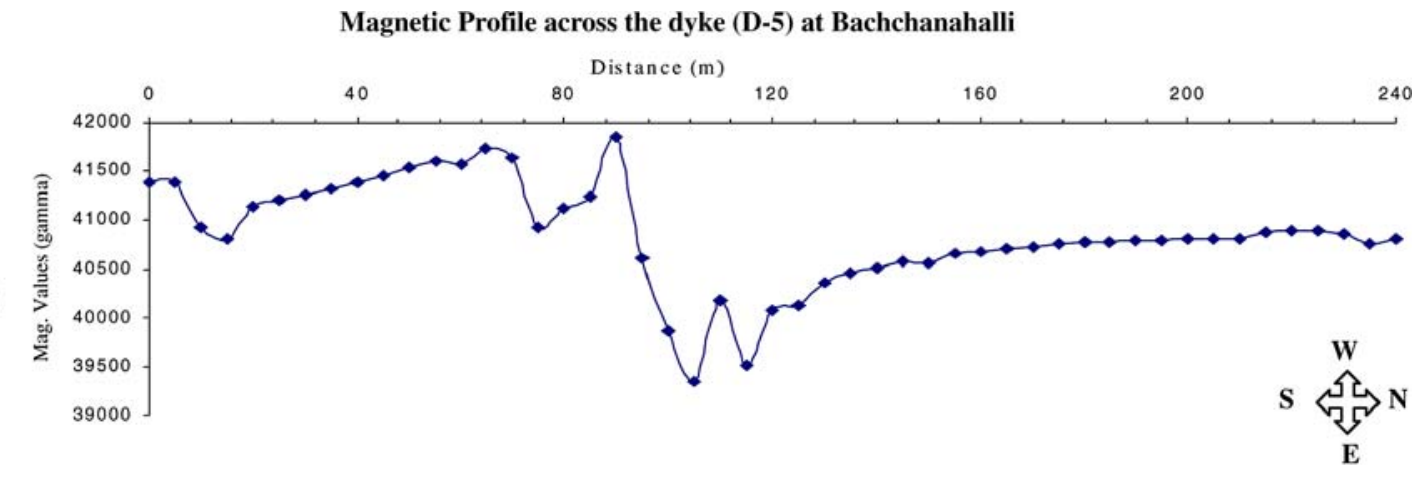

(b)

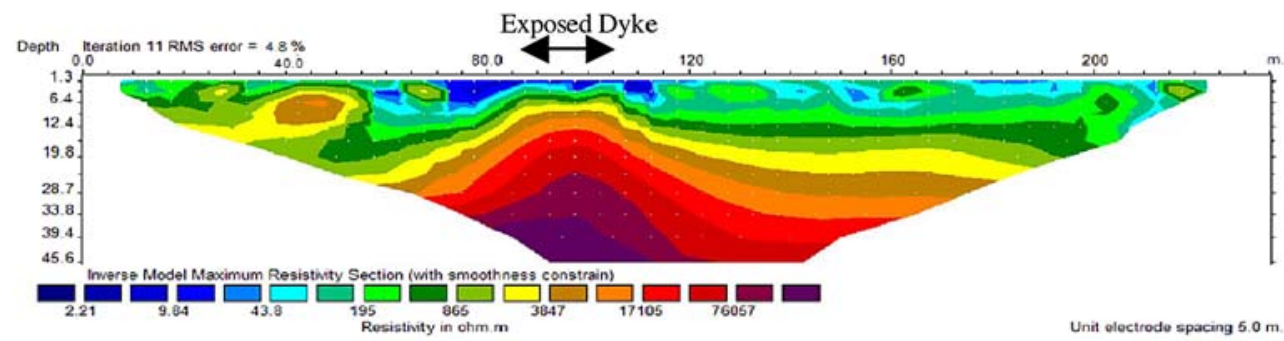

(c)

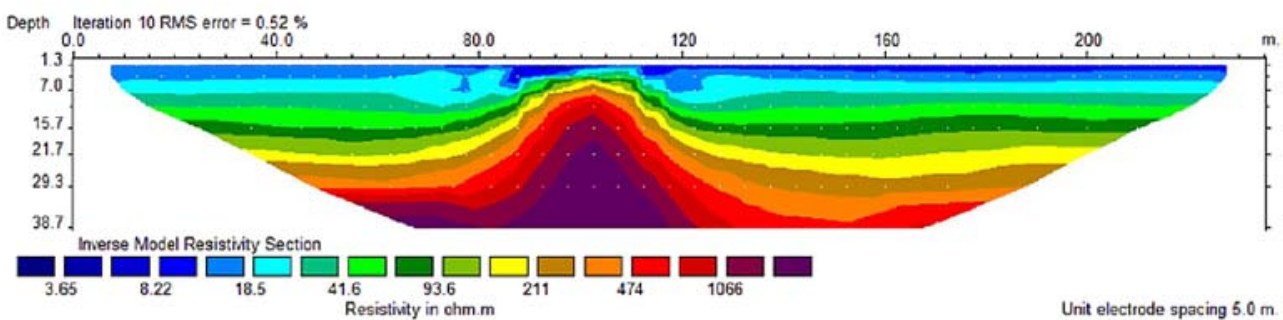

(d)

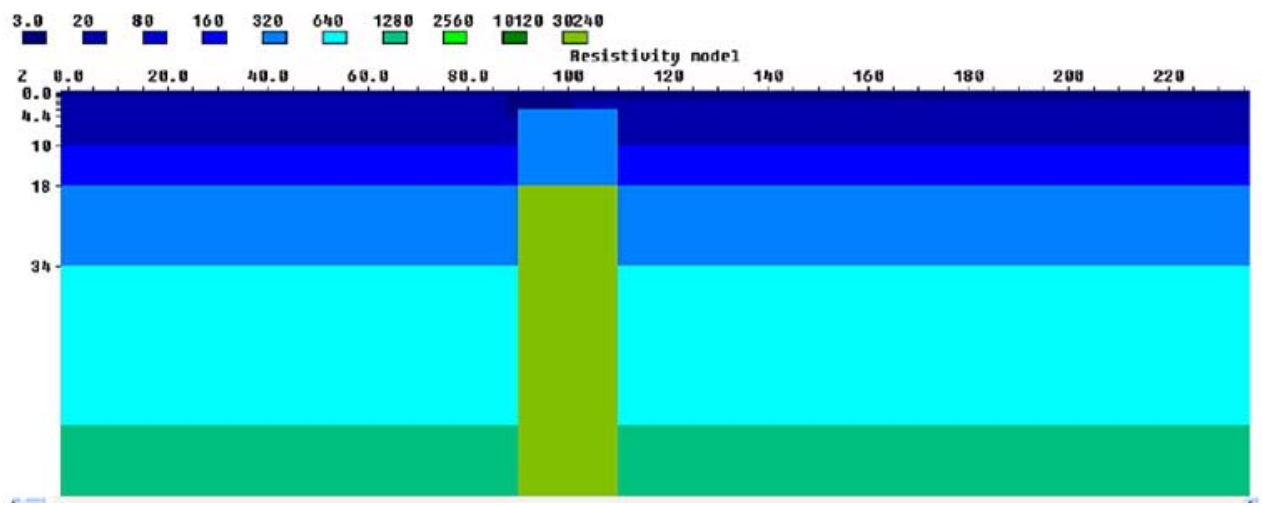

Fig. 4 (a) Magnetic profiles, (b) Electrical resistivity imaging across the dyke (D-5) at Bachchanahalli, (c) Synthetic ER image for a 20 m thick vertical dyke and (d) Physical representation of dyke intrusive in the layered subsurface

sistivity was $8-100 \Omega \mathrm{m}$. The resistivity increases at deeper levels $(100-80,000 \Omega \mathrm{m})$ indicating a more resistive stratum at a deeper level. The synthetic ER image for a $20 \mathrm{~m}$ thick vertical dyke of high electrical resistivity $(30,240 \Omega \mathrm{m})$ in a layered formation has shown close resemblance with ER image of field data (Fig. 5) and boosted the reliability of the field result.
The resistivity image reveals that it is resistive at a deeper level. The dyke is working as a barrier to groundwater movement. Since the gradient in the groundwater level is dipping towards the north, the contact zone at the south margin of the dyke with the host rock, which is weathered and fractured to a depth of $20 \mathrm{~m}$, will be a good location for a borehole or well. It is also possible that the ground- 
Fig. 5 Synthetic ER image for lineament (representing vertical weak zone (fracture/fault) inter-bedded in a layered formation) at: (a) shallow and (b) deep levels

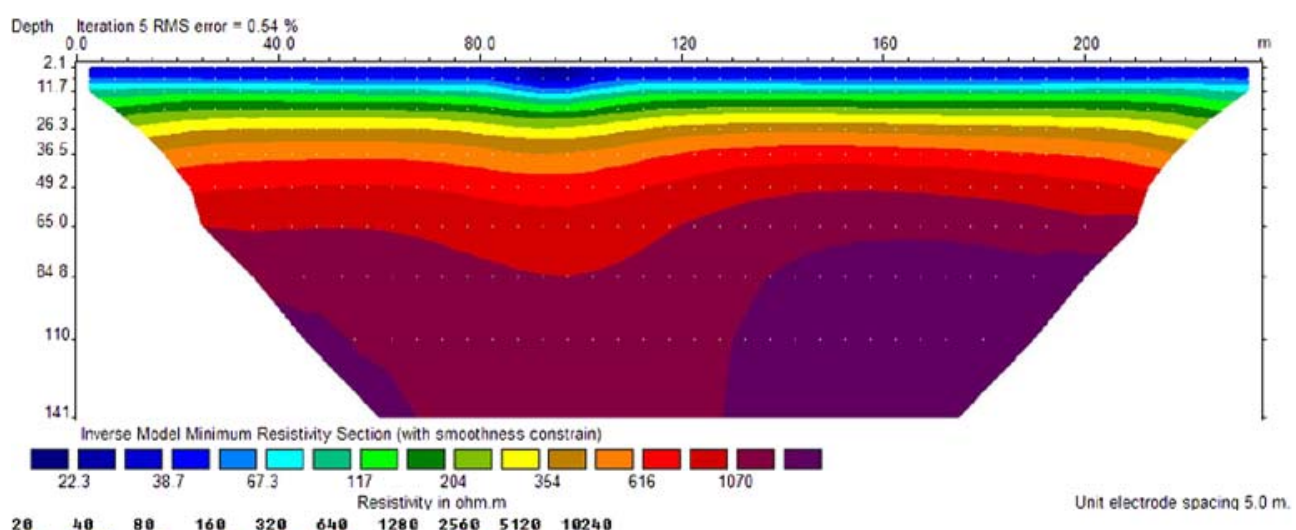

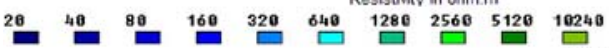
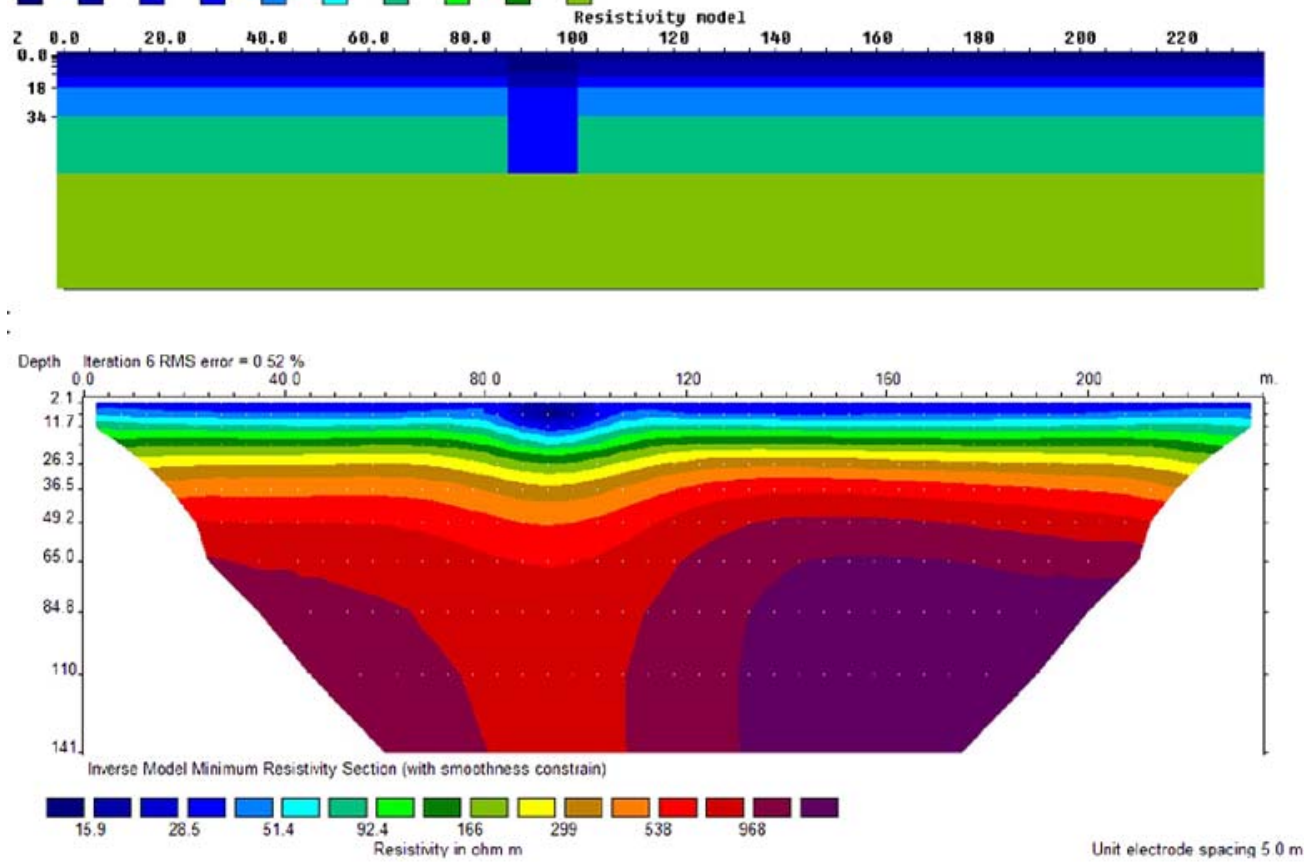

$20 \quad 40 \quad 80 \quad 160 \quad 220 \quad 640 \quad 1280 \quad 2560 \quad 5120 \quad 10240$

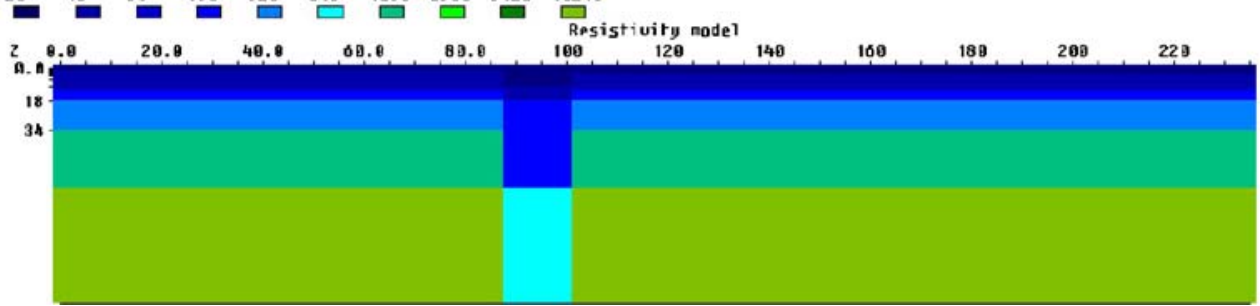

water moves laterally near the dyke i.e. towards the east and/ or west and passes through the weaker zones of the dyke to maintain the northward flow governed by hydraulic gradient. These weaker zones could not be identified due to inherent ambiguity.

\section{Lineament (L-2) at Mandikal tank}

A lineament was observed in Mandikal tank (L-2), but it was not clear whether it represents a 2-D structure that extends to a deeper level indicating a possible waterbearing zone. To characterize the lineament (i.e. major fracture/fault), ERI was carried out across the lineament and the ER image was compared with the synthetic ER image of low resistive vertical feature inter-bedded in layered formation. The synthetic ER image for a $12 \mathrm{~m}$ thick vertical body of low resistive $(640 \Omega \mathrm{m})$ has shown the close resemblance with the field. This feature is almost a vertical fracture, but it appears as tapering into a cone shape because of unequal vertical and horizontal scale (ratio: 0.5 ). The self potential profile has also shown a very pronounced low anomaly over this zone, which confirms the presence of a lineament (Fig. 6a). A borehole drilled in this zone has reported a yield of 1,302 galon per hour (gph). The water level in the borehole was $14 \mathrm{~m}$ below ground level (bgl). The boreholes and wells existing around this tank supply water for 
Self Potential profile across the lineament (L-2) at Mandikal Tank

(a)

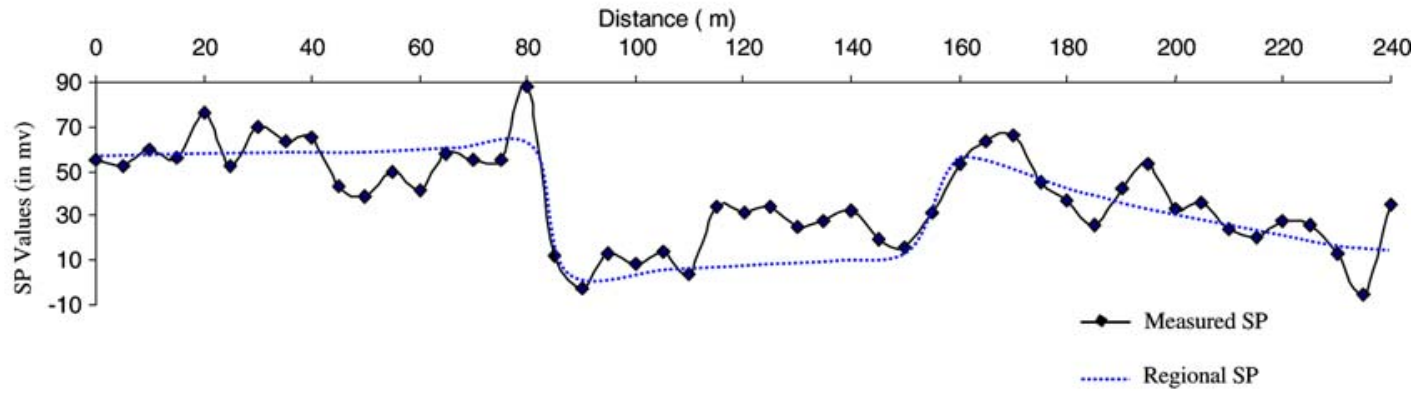

(b)

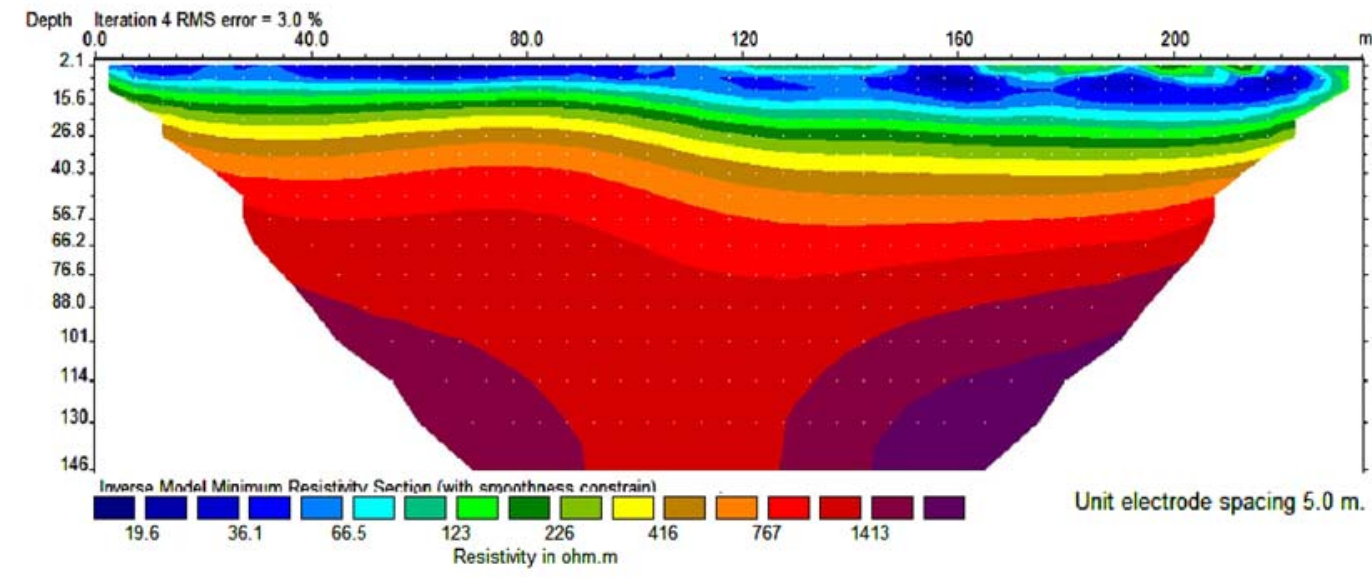

Resistivity Image with pole-pole array

Fig. 6 (a) Self Potential profiles and (b) Electrical Resistivity Imaging across lineament (L-2) at Mandikal Tank

SP profile across the lineament (L-1) at Bairasagarakere

(a)

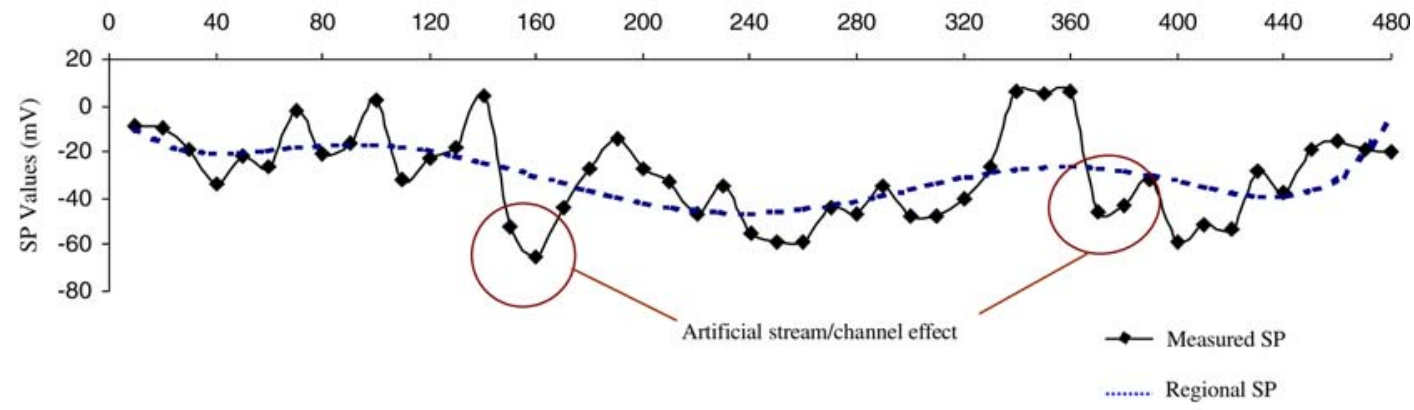

(b)

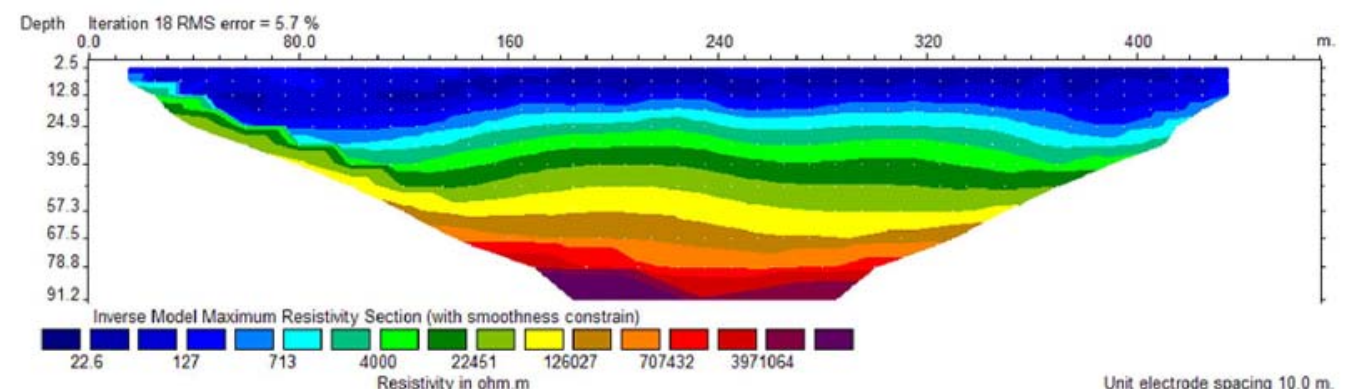

Resistivity section with Wenner-Schlumberger array

Fig. 7 (a) Self Potential profiles and (b) Electrical Resistivity Imaging across lineament (L-1) at Bairasagarakere 
drinking and domestic purposes for the entire Mandikal village. One stream follows this lineament, which itself is indicative of the weaker zone. Thus, all the observations indicate that this lineament might be either a fault zone or a major fracture zone. It apparently continues at deeper level (approximately $100 \mathrm{~m}$ ) and may be a suitable site for a high yielding borehole. The high yielding zone ranges from 90 to $125 \mathrm{~m}$.

\section{Lineament (L-1) at Bairasagarakere tank}

The lineament L-1 marked in Fig. 1, at Bairasagarakere, is indicated by a weak SP anomaly but does not register significantly in the resistivity image (Fig. 7b). The two sharp SP lows circled in Fig. 7a are the effect of an artificial stream channel. The SP has shown a regional low in the middle portion, but there is no signature in the resistivity section. The possible cause for the SP lows may be a very thin fracture, which could not be reflected due to its dimension. The resistivities are also very high below $25 \mathrm{~m}$. Thus the lineament is only a surfacial linear feature. Similar results have also been observed over lineament L-3 at Paiyuru (Fig. 2).

In general, magnetic, SP and resistivity have shown a response to the presence of lineaments whenever a strong magnetic susceptibility/resistivity contrast exist with the host rock in the surveyed area. Most of the dykes in the area have high resistivity at deeper levels and may be hindering the groundwater flow. The lineaments, which have been shown as fracture zones in the geomorphological map are only surfacial except the lineament L-2 at Mandikal tank. This is either a major fracture or a fault zone, which was confirmed by the existing boreholes in the surface water tank.

\section{Conclusion}

Integrated studies are necessary in hard rock areas to ascertain the presence of lineaments and dykes. In general, magnetic methods, SP and resistivity have shown response to the presence of lineaments whenever a significant resistivity/magnetic susceptibility contrast exists with host rock in the surveyed area. Mostly dykes are weathered at shallow depths (to $8 \mathrm{~m}$ ) and resistive at deeper levels. In relation to the groundwater flow the dykes are resistive i.e. behaving as barriers for groundwater movement. The contact zone of the dyke with the host rock in the upstream side is a good groundwater potential zone. These parameters will be useful for multi-layered aquifer modeling.

Studies have clearly indicated that the lineaments marked in the geomorphological map alone will not reveal groundwater potential zones. Resistivity imaging is the preferable tool to characterize the productive lineaments. Most of the lineaments/fractures shown in the geomorphological map are only surfacial features, except the lineament at Mandikal tank, which may be a fault zone or a major fracture. This lineament acts as a significant groundwater resource. The synthetic model of the lineaments has supported the interpretation of field data, that it is a major vertical fracture/fault or dyke.

Acknowledgment We are thankful to Dr. V. P Dimri, Director, NGRI, Hyderabad for according permission to publish this paper. We thank to Dr. R. L. Dhar and Sri. S. C. Jain for their valuable discussion and suggestions. The Department of Science and Technology (Government of India) has financed the investigations. Authors are also grateful to reviewers (Sue Duncan, Dr. Perry Olcott, Dr. Allen Rodhe and Dr. Mehrdad Bastani) for their critical review and valuable suggestions.

\section{References}

Ahmed MV (1964) A laboratory study of streaming potentials. Geophys Prospect 1(1):49-64

Atchuta Rao D, Ram Babu HV Sanker Narayan PV (1981) Interpretation of magnetic anomalies due to dikes: The complex gradient method. Geophysics 46:1572-1578

Baker SS, Cull JP (2004) Streaming potential and groundwater contamination. Explorat Geophys 57(1):41-44

Barker R, Rao TV, Thangarajan M (2001) Delineation of contaminant zone through electrical imaging technique. Curr Sci 81(3):277283

Barker RD (1978) The offset system of electrical resistivity sounding and its use with a multi-core cable. Geophys Prospect 29:128143

Barker RD (1992) A simple algorithm for electrical imaging of the subsurface. First Break 10:53-62

Chand R, Chandra S, Rao VA, Singh VS, Jain SC (2004) Estimation of Natural Recharge and its Dependency on Subsurface Geoelectric Parameters. J Hydrol 299:67-83

Edet AE, Okereke CS, Teme SC, Esu EO (1998) Application of remote sensing data to groundwater exploration: A case study of the Cross River State, southern Nigeria. Hydrogeol J 6(3):394 404

Fagerlund F, Heinson G. (2003) Detecting subsurface groundwater flow in fractured rock using self potential methods. Environment Hydrol 285:114-124

Fitterman DV (1979) Calculation of self potential anomalies near vertical contacts. Geophysics 41(2):195-205

Griffiths DH, Barker RD (1993) Two-dimensional resistivity imaging and modeling in areas of complex geology. J Appl Geophys 29:211-226

Griffiths DH, Turnbull J (1985) A multi-electrode array for resistivity surveying. First Break 3(7):16-20

Griffiths DH, Turnbull J, Olayinka AI (1990) Two-dimensional resistivity mapping with a computer- controlled array. First Break 8:121-129

Gustafsson P (1994) SPOT satellite data for exploration of fractured aquifer in semi-arid area in southern Bostwana. Appl Hydrogeol 2(2):9-19

Haricharan P, Ramlinga Reddy K, Murthy BVS (1984) An example of determining parameters of a dolerite dyke through resistivity survey. Geoviews xi(1):35-42

Koefoed O (1979) Geosounding Principles 1: Resistivity sounding measurements. Elsevier Science Publishing Co., Amsterdam

Krishnamurthy NS, Rao VA, Negi BC, Kumar D, Jain SC, Ahmed S, Dhar RL (2001) Electrical, self potential and mise-à-la-masse investigations in Maheshwaram watershed, Andhra Pradesh, India. Tech. Rep. no. NGRI-2001-GW-314

Krishnamurthy NS, Rao VA, Negi BC, Kumar D, Jain SC (2003a) Geophysical Exploration for Identification of old workings in East Basuria, NGRI Technical Report No. NGRI-2003-GW-389

Krishnamurthy NS, Kumar D, Marc D, Henri R (2003b) Integrated geophysical investigations. Vol. 1 of scientific report of IFCPAR project no. 2013-1, 2003, pp 65 
Lattman LH, Parizek RR (1964) Relationship between fracture traces and the occurrence of groundwater in carbonate rocks. J Hydrol 2:73-91

Loke MH (2001) Rapid 2D resistivity forward modeling using the finite difference and finite element methods. RES2DMOD version 3.0 manual, pp 11

Loke MH, Barker RD (1996) Rapid least-squares inversion of apparent resistivity pseudo sections using a quasi-Newton method. Geophys Prospect 44:131-152

Mabee BS, Curry PJ, Hardcastle KC (2002) Correlation of Lineaments to ground water inflows in bedrock tunnel. Ground Water 40(1):37-43

Mabee SB, Hardcastle KC, Wise DU (1994) A method of collecting and analyzing lineaments for regional scale fractured-bedrock aquifer studies. Ground Water 32(4):884-894

Magowe M, Carr JR (1999) Relationship between lineaments and ground water occurrence in western Bostwana. Ground Water 37(2):282-286

Mahmood A (1996) Lineaments as groundwater exploration guides in hard rock terrain of arid regions. Can J Remote Sens 22(1):108116
Mukerjee PK (1986) A textbook of geology, The World Press Private Limited, pp. 543

Parkhomenko EI (1971) Electrification phenomena in rocks, New York, NY, pp 285

Sander P (1997) Water well siting in hard rock areas: identifying promising targets using a probabilistic approach. Hydrogeol J $5(3): 32-43$

Sander P, Minor TM, Chesley MM (1997) Groundwater Exploration based on lineament analysis and reproductivity tests. Ground Water 35(5):888-894

Siddiqui SH, Parizek RR (1971) Hydrogeology factors influencing well yields in folded and faulted carbonate rocks in central Pennsylvania. Water Resour Res 7(5):1295-1312

Wanfang Z, Beck FB, Stephenson JB (1999) Investigation of groundwater flow in karst areas using component separation of natural potential measurement. Environ Geol 37(1-2):19-25

Yin ZY, Brook GA (1992) The topographic approach to locating high yield wells in crystalline rocks: Does it work? Ground Water 30(1):96-101 